\title{
Social justice, the raison d'etre of clinical legal education
}

\author{
Ajay Pandey ${ }^{1}$ \\ Accepted: 28 December 2020 / Published online: 5 February 2021 \\ ๑) O.P. Jindal Global University (JGU) 2021
}

Clinical Legal Education (CLE) is not a new concept for Indian law schools. It is at least as old as the 1970s. ${ }^{1}$ However, CLE is still in a fledgling state despite almost fifty years of its introduction into legal education in India. Promotion and strengthening of CLE is a desirable aspiration to not only orient, prepare, build, and inspire legal professionals for social justice, but also to bring law, its language, its processes, mechanisms and institutions and their language closer to the masses. CLE, with its macro-objective of achieving social justice, has the potential to bring such transformation in and through legal education. Legal educators and others ${ }^{2}$ with particular interest in social justice have been making efforts to establish, promote, strengthen, and orient CLE in India. ${ }^{3}$

The need for CLE in India has its rationale and urgency in several concerns relating to issues of equal access to justice, legal aid, rule of law, governance, human rights, etc. These concerns include the quest to make legal education socially relevant and inclusive, while making it an instrument of addressing the disconnect between the promises of law and their reality. India has over sixteen hundred law schools. They present an opportunity with immense potential to translate constitutional guarantees of various fundamental provisions, including the right to a dignified life and the right to equality before law and its equal protection, into reality. The

\footnotetext{
${ }^{1}$ For example, Banaras Hindu University's legal aid clinic at the law faculty has been functioning since 1977; see https://bhu.ac.in/law/legal-aid-clinic.html. Accessed 12 December 2020. Earlier, in 1969, some teachers and students of the law faculty of Delhi University voluntarily and informally set up a legal services clinic. See N R Madhava Menon, Clinical Legal Education (Eastern Book Company 1998) 18.

2 They include lawyers, activists, NGOs, human rights workers, etc. The Global Alliance for Justice Education (GAJE) is an organisation of such individuals and entities with its roots connected to Professor N R Madhava Menon. To know about GAJE, see, http://www.gaje.org. Accessed 12 December 2020.

3 For example, the Menon Institute of Legal Advocacy Training (MILAT) played a key role in organising training of teachers in CLE in different parts of India. More efforts are needed to help in the development of a movement for CLE that would effect social justice and transform law schools as avenues where the needy and the helpless would confide and submit their quest for justice and access to justice and it would be adopted and pursued by students and professors until its logical conclusion through pedagogies of making law real and meaningful for the masses.
}

Ajay Pandey

apandey@jgu.edu.in

1 Jindal Global Law School, Sonipat, India 
need is to harness this potential and orient the resources that the law schools have in terms of their mandate, infrastructure, and human power, especially the young, amorphous, and promising minds. Promoting and strengthening CLE is a much required and desired way to transform India's legal education along these lines.

CLE, as a method of teaching and learning law, focusses on building lawyering skills and securing social justice. Globally, it has two main objectives - one micro and another macro. The micro-objective of CLE is to impart lawyering skills to students and its macro-objective is to achieve social justice. CLE's methodology of 'learning by doing' requires effective access of students and faculty to apply law to real situations and clients. This mandates a robust law clinic in law schools. If law schools are provided avenues to engage in real work as they teach, their teaching will be more effective, and they will provide much needed support in ensuring equal access to justice for all. For almost every law school course, CLE methods may be used to impart legal education. Thus, law school clinics need to be strengthened and oriented to provide avenues to different courses to adopt methods of CLE.

While methods of CLE help the learners to become practice-ready legal professionals, the opportunities that they provide to have ideas and ways to effect social justice ingrained in them are unparalleled. There could be several ways and avenues for the learners of law to learn skills of lawyers and their methods to manoeuvre the terrain of law and its mechanisms and institutions. They include internships with courts, judges, lawyers, law firms, and other vistas. What is unique to CLE is its justice mission. CLE can effect inclusion of the masses, with the last citizen as the first priority, in the main agenda of law. It is this potential of CLE that can transform the landscape of both legal education and access to justice for millions. It needs to be explored and oriented and not allowed to be lost. Inherent in the social justice mission of CLE is a much larger promise to make legal education more socially relevant and common people centric, particularly in a society like India. Such imaginative and expanded approaches in considering CLE will help legal education in making law real and meaningful for the masses. ${ }^{4}$

Legal literacy has been a facet of legal aid and access to justice. ${ }^{5}$ However, legal literacy initiatives have not yielded the desired results, especially in terms of them being translated into more effective legal aid and access to justice for the common populace. ${ }^{6}$ Through its learning and experiments with CLE, the Clinical Programmes

\footnotetext{
${ }^{4}$ Even some of the most fundamental promises of law do not seem real. They appear like fiction and not provisions of law that are real and meaningful for common people. In my classroom discussions, I often discuss these concerns with my students, and we wonder why common people would not consider law and its people, including law teachers and students, fictitious.

${ }^{5}$ Legal Services Authorities at different levels (national, states, district, and taluka), established through the Legal Services Authorities Act, 1987, are mandated to carry out initiatives of legal aid.

${ }^{6}$ The National Legal Literacy Mission, 2005-2010, for example, was a much-hyped initiative launched by the then Prime Minister of India. However, there is not much information available about its impact and how it was carried out and to what end. The Prime Minister, while launching the mission, did say that it was close to his heart. This is generally the plight of initiatives of legal literacy and legal aid. They have a lot of interest and desirability, but they often end up being emblematic and ceremonious with little or no impact.
} 
of Jindal Global Law School (JGLS) realised the need for making a shift from legal literacy to legal empowerment. ${ }^{7}$ Citizen participation to bring about good governance, vibrant democracy and rule of law is required to address the disconnect referred to above. As a new and unique addition, the idea of citizen participation clinics has to make a transformative contribution to the social justice mission of CLE, especially in a society like India that has enormous unmet legal needs of millions.

CLE has a distinct impact on students. ${ }^{8}$ Several students chose to work in public service areas because of their community engagement experience through CLE at JGLS. ${ }^{9}$ The more CLE is promoted in legal education; the more students will join the movement for social justice. This will help in the development of stronger constituencies to carry forward the objectives of justice education and make them real and meaningful for the common person. As more students learn through the methods of CLE, the nearer legal education reaches the goal of creating and congealing ${ }^{10}$ a culture for social justice, human rights, rule of law, democracy, good governance and citizen participation.

To explore resources and further build on them to promote CLE, law schools in India need to seriously appreciate the Bar Council of India's (BCI) requirement for each institution of legal education to establish and run a Legal Aid Clinic. ${ }^{11}$ This

\footnotetext{
${ }^{7}$ Legal literacy or legal awareness programmes are often preferred by law school clinics in India for their community outreach activities. However, their impact, sustainability, and continuity remain uncertain. Students would have a lot of enthusiasm for these activities, mostly during the initial phase of the semester. However, it would wane, in most cases, as they would have different priorities as the semester would progress, including those related to examinations. Then, during vacations, they would not be there to continue with their community work. Processes of legal empowerment require focus on developing communities as effective participants in democracy. Legal empowerment promotes citizen participation and does not hold community members as mere recipients of information. Community members, as participants in processes of legal empowerment, learn by doing. Their participation ensures sustainability, continuity, impact and expansion of community engagement and empowerment initiatives.

${ }^{8}$ Students in the league - Shireen, Dev, Kudrat, Meher, and several others - were actively involved in the organization of the 7th worldwide conference of the Global Alliance for Justice Education (GAJE) at OP Jindal Global University (JGU), December 2013. Their contribution and learning is a student legacy of CLE that is carried on further by students at JGU and elsewhere. Clinical Programmes organized several conferences, conclaves, and workshops - international, national, and regional to build the momentum for CLE to transform legal education. The baton of the student league is passed on successfully year by year while multiplying its bearers into thousands. Shireen, now a faculty at JGLS, has supported the idea of this special CLE issue and I thank her for her continued support for CLE. Dev is a fine judicial officer. Kudrat, a lawyer and scholar, is spearheading a unique youth-run community conflict management and mediation initiative. Meher, a contributor to this issue of JGLR, is passionate about CLE and wants to pursue it as a career choice. Each of these students from the first batch of JGLS' five year law programme has an inspiring story of their contribution for and vision of public service. Through their mention, I wish to acknowledge hundreds of students, like them, for their zeal and work for social justice, the inspiration that they are, and the promises that they hold.

${ }^{9}$ Several students shared their experiences of how clinical courses at JGLS change their thinking towards public service. Before these experiences they thought of life after law school in a corporate law firm working late in the nights and hitting the bar during weekends.

${ }^{10}$ I have adopted the phrase 'creating and congealing' from the writings of Professor BS Chimni.

11 'Each institution shall establish and run a Legal Aid Clinic under the supervision of a Senior Faculty Member who may administer the Clinic run by the Final year students of the Institution in cooperation with the Legal Aid Authorities with list of voluntary lawyers and other Non-Government Organizations engaged in this regard in the locality generally from which the student community of the Institution hail from.' Schedule III, s 11, Bar Council of India Rules, 2008.
} 
requirement could be used as a basis to coalesce more resources and support for CLE. The 1973 Expert Committee Report and the 1977 Juridicare Report ${ }^{12}$ emphasised the importance of the provision of legal aid and the involvement of law students and law teachers in it. ${ }^{13}$ In its 2002 report, the Law Commission of India suggested that clinical legal education be mandatory. ${ }^{14}$ The Constitutional guarantees of a life of dignity to all, ${ }^{15}$ with the right to equality before the law and equal protection of the laws, ${ }^{16}$ added by a directive to the state to secure access to justice and legal aid, ${ }^{17}$ draw an extraordinarily inspiring national mandate for legal aid and equal access to justice. In addition, several of India's treaty obligations further strengthen this regime. The National Legal Services Authority (NALSA) also has the mandate to strengthen and promote law school clinics and clinical legal education in consultation with the BCI. ${ }^{18}$

However, and as stated above, CLE is yet to secure its much-desired place in India's legal education. From lack of adequately trained faculty to absence of required infrastructure and financial resources, various factors are cited as reasons for the inhibited growth and development of CLE in India. ${ }^{19}$ Legal prohibition for full time law teachers to practise law $^{20}$ is also regarded as a hurdle in the growth and development of CLE. While some of such policy shifts may be secured in due course, the vast arena for social justice outside and beyond court-based approaches needs to be explored. This arena includes legal empowerment of communities, street law initiatives, work with para legal volunteers, services to rural and marginalised populations and weaker sections of society, public interest litigation, human rights

\footnotetext{
12 Government of India, Ministry of Law, Justice and Company Affairs, Equal Justice-Social Justice: Report of the Juridicare Committee (1977) and Government of India, Ministry of Law, Justice and Company Affairs, Processual Justice to the People: Report of the Expert Committee on Legal Aid (1973), referenced in Frank S Bloch and Iqbal S Ishar, 'Legal Aid, Public Service and Clinical Legal Education: Future Directions from India and the United States' (1990) 12(1) Michigan Journal of International Law. 13 'Properly channelized and co-ordinated, the idealism and zeal of enthusiastic youth in our law schools can meet these new demands and help transform our society to desirable goals.' Processual Justice to the People: Report of the Expert Committee on Legal Aid (n 12) 156. 'It must not be forgotten that significant sector of human resources for legal services to the poor is student power. It can destroy, if misguided, but equally it can build, if canalized in constructive channels. Law teachers, legal researchers and law students, once harnessed to the process of legal aid will produce spectacular and substantial results.' Equal Justice-Social Justice: Report of the Juridicare Committee (n 12) 67-68.

${ }^{14}$ Law Commission of India, 184th Report on The Legal Education \& Professional Training and Proposals for Amendments to the Advocates Act, 1961 and the University Grants Commission Act, 1956 (2002).

15 The Constitution of India, 1950, art 21.

16 The Constitution of India, 1950, art 14.

17 The Constitution of India, 1950, art 39A.

18 The Legal Services Authorities Act, 1987, s 4(k).

19 Some of the factors responsible for the insignificant and unsatisfactory development of CLE in India have been mentioned in UNDP report, 'A Study of Law School Based Legal Service Clinics' (2011). https://www.in.undp.org/content/india/en/home/library/democratic_governance/a_study_of_law_schoolbasedlegalservicesclinics.html. Accessed 12 December 2020.

20 The Advocates Act, No 25 of 1961, India Code (1961); Bar Council of India Rules, Gazette of India, 2001, Part VI, ch II, Section VII, para 49 (Sept. 6, 1975) - 'An advocate shall not be a full-time salaried employee of any person, government, firm, corporation or concern, so long as he continues to practice . ..
} 
advocacy, etc. Many of such aspects of the social justice mission of CLE found a prominent supporter and promoter in Professor N R Madhava Menon.

Widely referred to as the father of modern legal education in India, Professor $\mathrm{N}$ R Madhava Menon constantly appealed to legal educators to strive to make legal education more socially relevant. A leading light for the idea of justice education, he was instrumental in the establishment of the Global Alliance for Justice Education (GAJE). Having established the first national law school in India and thereby having paved the way for several of them across India, he dedicatedly worked for and shaped the landscape of legal education. In his vision, 'socially relevant legal education' and 'justice education', the two differently worded terms, had the same meaning and purpose. ${ }^{21}$ Dedicating this special issue to him is an effort to not only pay tribute to his untiring contribution to the social justice mission of CLE but also to reiterate the need to invigorate the zeal for CLE and its macro purpose in legal education.

The contributors of this issue have predominantly dwelled on social justice and ideas for realising social justice through legal education and hence transforming it into justice education and making it more socially relevant. Professor Menon promoted and supported these ideas and encouraged experiments with CLE to promote them. Amongst the eight articles in this issue, two - Frank Bloch's 'NR Madhava Menon: The guiding light for global clinical legal education' and Richard Grimes' 'A tribute and a legacy: Clinical legal education and the bountiful harvest' - have specifically discussed Professor Menon's work for CLE and the legacy that he created for justice education. The critical role that Professor Menon played in the formation and development of GAJE and the imprint that he made globally for justice education is captured in Frank's article. A stalwart of the global CLE movement and GAJE, Frank had an extensive association with Professor Menon and his article is a rare addition in the issue to encourage the readers to delve into the idea of justice education that Professor Menon espoused.

Grimes, while paying his tribute to Professor Menon's contributions and his legacy in his discussion on the past, present and future of CLE, points towards massive unmet legal needs globally, owing to inequalities and lack of access to lawyers and

\footnotetext{
21 A way to follow Professor Menon's reference to 'socially relevant legal education' and 'justice education' would be to consider various phrases that he often used, particularly in forums and gathering of CLE. Some of them include, 'unmet legal needs of communities', 'legal services for the poorest of the poor, the most vulnerable and the marginalized', 'legal empowerment of communities', 'governance, democracy, rule of law, and citizen participation', 'rural work and gram nyayalayas', 'legal services to develop as public enterprise', etc. In an attempt to, inter alia, explore ideas for a socially relevant legal education, the University Grants Commission (UGC) organised regional workshops more than four decades ago. Through this initiative, Professor Upendra Baxi asked, '[c]an a law curriculum be socially relevant and yet ignore the fact that India is an overwhelmingly a rural country? Or that it is a country full of underprivilege, exploitation and destitution?' He further commented, '[i]f a large number of students and teachers are brought into frequent organized confrontations with "misery and exploitation, disease and malnutrition, poverty, illiteracy, unemployment and squalor in the midst of plenty", disquiet, discomfort and doubt will assail minds in classrooms, libraries and laboratories. The result may well be a more socially relevant higher education.' See, Towards a Socially Relevant Legal Education: A Consolidated Report on the University Grants Commission's Workshop on Modernization of Legal Education. https://www.ugc.ac.in/oldpdf/pub/report/1.pdf. 9, 27. Accessed 20 December 2020. These questions and remarks remain apt and relevant, for the quest of a socially relevant legal education, even today.
} 
justice. For unmet legal needs, Grimes indicts society - past and present. Unmet legal needs of underprivileged communities concerned Professor Menon and he often voiced it and exhorted legal educators to address it. Referring to the charge that the National Law Schools cater largely to the private corporate sector and neglect the needs of public law and governance, he emphasised the need to re-orient legal education to serve the general public and the marginalized sections more than what it did then (when he made this reference). ${ }^{22}$

Four other articles bring perspectives on various aspects of social justice work from Nepal, Bangladesh, the Maldives, and South Africa. Their authors, respectively, Yubaraj Sangroula, Mizanur Rahman, Marium Jabyn, and David McQuoidMason, have crafted aspects of legal aid and access to justice, community service, and human rights within the overarching realm of social justice and justice education. Appreciation of the issues, challenges, and opportunities they have pointed out will strengthen CLE. Jeff Giddings, in his article, considers various challenges that CLE programmes have in responding to the COVID-19 situation. Sital Kalantry and Rachael Hancock have presented a case for transnational law clinics' collaborative and joint work, while discussing their collaborative clinic between Cornell Law School and National Law University of Delhi. It is hoped that these contributions will help in furthering CLE with new ideas, approaches and collaborative efforts.

The interviews with Ved Kumari and Flavia Agnes - the former to capture the landscape of CLE by a frontline contributor to CLE in India and the latter for CLE to imagine, explore, and expand its role in responding to crises and complexities that the ever-growing regime of violence against women presents - are prominent additions in this issue and it is hoped that they will benefit the readers in several ways, including in considering the techniques of discovering, narrating and presenting experiences and thinking and bringing them into the public domain with value addition for the present and the future.

One of the key needs in promoting CLE is to have more literature and knowledge resources. The two books that have been reviewed for this issue also serve as a reminder for new work in that stream. Though these books are old - Clinical Legal Education (edited by N R Madhava Menon) is from 1998 and The Global Clinical Movement: Educating Lawyers for Social Justice (edited by Frank S Bloch) is from 2011 - they have strong grounding in ideas of social justice and justice education and are of immense relevance even today. Inclusion of their reviews in this issue is to serve on one hand as an inspiration, inter alia, for collaborative work to promote CLE, and on the other to remind the constituencies of CLE about the need for more such books to further the legacy.

While presenting this issue, I cannot refrain from mentioning the current pandemic of COVID-19 that has presented situations for us to imagine new ways to survive. For the last couple of decades, the ways that we adopted to take the world forward have brought in unprecedented and monstrous inequalities where those who have, have everything in too much abundance, even the wherewithal to destroy

\footnotetext{
22 Menon keynote address, titled, 'Good Rural Governance, Citizen Participation and Clinical Legal Education', delivered at IRRAD (now as SM Sehgal Foundation and not as its part as it existed then), JGLS International Conference on Good Rural Governance and Citizen Participation, March 1-3, 2012. (On file with author).
} 
everything, and those who do not have, do not have enough to survive a day and have no resources to even think of building their tomorrow. The plight of migrant workers when our 'smart cities" ${ }^{23}$ during pandemic lockdowns watched their helpless and hapless exodus in various conditions of torture, pain, and depravity, back to their villages and cities of origin, did not shake our conscience for effective responses and corrections. We build our cities in ways that leave them bereft of care, compassion, social justice, and human dignity, and yet call them 'smart'. The initiative of Aatmanirbharta (self-reliance) ${ }^{24}$, though much needed, in its essence, to ensure dignity and worth of every single human being, would have no meaning if our imaginations and dispensations tend to deprive the masses of social justice. Pursuit of education and legal education must result in achieving larger goals of light, liberation, and justice, and exclusion of anyone from this ambit should be taken as a failure on the part of those who are in this pursuit. A socially relevant legal education needs to be pursued as a matter of trusteeship. Its pursuers need to act on behalf of the masses - the common people, the peasant, the labourer, the homeless - as their trustees in ensuring that it serves their end and they be at the centre and heart of this pursuit. Several such ideas associated with justice education are needed to transform legal education and CLE is potentially poised for it.

Publisher's Note Springer Nature remains neutral with regard to jurisdictional claims in published maps and institutional affiliations.

\footnotetext{
${ }^{23}$ Information on the idea of smart cities, as being developed and promoted in India, may be accessed through http://smartcities.gov.in/content/. Accessed 20 December 2020. More effective realisation of social justice and human rights should be the main objective of smart cities. Habitations where the most vulnerable dwellers - children, women, elderly, differently abled, and poor - feel safe, protected and enabled, should be termed smart. Citizen participation clinics can infuse these ideas in our thinking and culture while exploring new horizons for legal education and its role.

${ }^{24}$ To know about this initiative, see https://aatmanirbharbharat.mygov.in/. Accessed 20 December 2020. CLE's expanded vision of social justice includes the idea of aatmanirbharta. It is important for aatmanirbhar bharat (self-reliant India) initiative to ensure that common people become self-reliant and lead a life of dignity. Indeed, human dignity and self-reliance go hand in hand. The right to a dignified life and its guarantee is the most fundamental provision of law, generally, and particularly in the context of India. In fact, the guarantee of a dignified human existence is more sacred than a mere provision of law. It is a promise that 'we the people' made to 'we the people'. For CLE to venture in this realm would mean to go beyond conventional ideas and practice of law and to embrace imaginations that would effect vibrant democracy, rule of law, and human dignity. It is in achieving self-reliance and dignity that law will find its true meaning. Self-reliance and dignity of individuals and institutions at the grassroots (panchayats and municipalities) need special emphasis. Mahatma Gandhi's vision of Gram Swaraj (village self-rule or self-governance) can provide the desired direction to aatmanirbhar bharat initiative and CLE can get the necessary cues for its exalted role in community service at the grassroots. The contribution that Mahatma Gandhi made to public life and the role that he played, especially as a mass leader and community organiser, should inspire law students and legal professionals to assume larger roles in society than what they can normally take up within the confines of law courts and law firms. His example holds additional relevance here as he was a lawyer too. CLE can help legal education prepare and orient students for such roles. Through these roles, law students can engage in addressing larger concerns of governance deficit, ethical deficit, environment, malnutrition, violence against women, inequalities etc. and help law in reaching its overarching goal of justice while ensuring dignity and self-reliance of the common person.
} 